www.jmscr.igmpublication.org

Impact Factor 3.79

Index Copernicus Value: 5.88

ISSN (e)-2347-176x ISSN (p) 2455-0450

crossref DOI: _http://dx.doi.org/10.18535/jmscr/v4i02.03

Journal Of Medical Science And Clinical Research

\title{
Serum $\beta$ Lymphocyte Activating Factor of Tumor Necrosis Super family (BAFF) and a Proliferation Inducing Ligand (April): Correlation with Activity and Chronicity Indices in Egyptian Adolescent Lupus Patients with and Without Nephritis
}

\author{
Authors \\ Eman Hassan Elsayed Hassan ${ }^{1}$, Hanaa Mahmoud Ali Donia ${ }^{2}$ \\ ${ }^{1}$ Lecturer of Internal Medicine (Rheumatology), Department of Internal Medicine, Faculty of Medicine, \\ Alexandria University, Egypt \\ ${ }^{2}$ lecturer of Clinical Pathology, Department of Clinical Pathology, Faculty of Medicine, Alexandria \\ University, Egypt
}

\begin{abstract}
Dysfunction of the B lymphocyte is considered to be involved in the pathogenesis of lupus nephritis (LN) intrarenal B cells have been found in several forms of inflammatory kidney disease. B lymphocyte stimulator signaling pathway by BAFF and its homologue APRIL has an important role in the selection, maturation and survival of $B$ cells and plays a significant role in the pathogenesis of systemic lupus erythematosus (SLE). We aim at this study to investigate the serum level of BAFF, APRIL in Egyptian adolescent lupus nephritis patients and correlate their levels with grade and chronicity indices of LN and compare their result with their counterparts of adolescent lupus patients without lupus nephritis. This study included 60 adolescent patients: Group 1: 20 adolescent SLE patients with lupus nephritis. Group 2: 20 adolescent SLE patients without lupus nephritis. Group 3: 20 age and sex matched healthy subjects served as control group. In this study, BAFF ranged from 4.26-182., 3.25-166.0 and 2.1-30.0 with the mean of 88.6 $\square 42.6,69.2 \square 27.6$ and 12.9 $\square 3.25$ for group I, II and III respectively, there were statistical significant differences between the three studied groups regarding BAFF, group I has statistically higher values than group II and III, also group II has statistically higher values than group III. APRIL ranged from 3.0-40.0, 2.0-42.5 and 7.0-45.0 with the mean of 7.98 \pm 8.25 , $9.12 \pm 7.88$ and $14.89 \pm 7.98$ for group I, II and III respectively, there were statistical significant differences between the three studied groups regarding APRIL, group III has statistically higher values than group I and II, also group II has statistically higher values than group I. Regarding group I, there was positive significant correlation between ANA, activity index and chronicity index with BAFF, there was negative significant correlation between ANA, renal activity index, and chronicity index with APRIL. Regarding group II, there was positive significant correlation between ANA and Anti-DNA with BAFF, while there was negative significant correlation between ANA with APRIL.

Key Words: Adolescent SLE, lupus nephritis, BAFF, APRIL
\end{abstract}

\section{INTRODUCTION}

Renal disease in systemic lupus erythematosus

(SLE) carries significant morbidity and mortality. ${ }^{(1-}$

${ }^{5)} \mathrm{Up}$ to $26 \%$ of patients with diffuse proliferative

lupus nephritis (LN) develop end-stage renal failure $^{(6-9)}$ and the mortality increases by eightfold as compared with the general population. ${ }^{(5)}$ 
Although a better understanding of autoimmunity in SLE has been achieved, reliable biomarkers of treatment response in both SLE and LN have yet to be found. As B cells have a pivotal role in the pathogenesis of SLE and autoantibody production, $\mathrm{B}$ cell activating cytokines have in recent years received increasing attention as both potential biomarkers and target molecules for new treatments. $^{(5)}$

B lymphocyte stimulator (BLyS), also known as B cell activating factor belonging to the tumour necrosis factor family (BAFF), and a proliferation inducing ligand (APRIL) are members of tumor necrosis factor (TNF) family and are important regulators of B-cell maturation, survival and function. ${ }^{(6)}$

Over expression of BLyS led to autoimmune manifestations, including nephritis and arthritis. ${ }^{(7)}$ In human studies, patients with SLE and rheumatoid arthritis have been shown to overexpress BLyS. ${ }^{(8-}$ ${ }^{11)}$ Renal lupus patients have also been shown to have higher levels of serum BLyS compared with SLE patients without renal involvement. ${ }^{(12)}$

A recent study demonstrated higher BLyS mRNA levels in glomeruli from patients with proliferative LN (PLN) compared with control tissue from pretransplant biopsies of living donors, ${ }^{(13)}$ indicating an important role of BLyS in this LN subset.

APRIL is involved in the induction and maintenance of B and T cell responses. ${ }^{(14)}$ In murine models, over expression of APRIL led to increased frequencies of B cells. ${ }^{(15)}$ Some studies have demonstrated raised serum levels of APRIL in patients with SLE $^{(16,17)}$ while in others, APRIL levels did not differ from values regarded as normal. ${ }^{(18)}$ APRIL levels have been shown to be lower in SLE patients with renal involvement compared with lupus patients without kidney disease, ${ }^{(12)}$ and APRIL mRNA levels were higher in the glomeruli of PLN patients compared with tissue from living donors. ${ }^{(13)}$

\section{Aim of the work}

Given the rising critical role of BLys and APRIL play in $\beta$-cell homeostasis, we aim at this study to investigate the serum level of BAFF, APRIL in Egyptian adolescent lupus nephritis patients and correlate their level with grade and chronicity index of LN and compare their result with their counterparts of adolescent lupus patients without lupus nephritis

\section{SUBJECT AND METHODS}

This study included 60 adolescent patients; they were subdivided into 3 groups:

- Group 1: 20 adolescent SLE patients with lupus nephritis fulfilling the systemic lupus international collaborating clinics (SLICC) 2012 criteria for diagnosis of $\mathrm{SLE}^{(19)}$

- Group 2: 20adolescent SLE patients without lupus nephritis.

- Group 3: 20 age and sex matched healthy subjects served as a control group.

\section{All patients were subjected to:}

- Detailed history taking and complete physical and mental examination.

- Laboratory investigations done for the studied group of patients included:

- Complete blood picture,

- liver enzymes (ALT, AST),

- renal function test (blood urea, serum creatinine, creatinine clearance, 24 hour urine proteins and urinary albumin creatine ratio).

- complete urine analysis,

- erythrocyte sedimentation rate (ESR),

- C-reactive protein (CRP),

- Serum complement C3 and C4 (assessed by nephelometry). ${ }^{(20)}$

- lipid profile including serum cholesterol, triglycerides,

- antinuclear antibodies (ANA) titre.

- antidouble stranded DNA antibodies (antids DNA) titre.

- Detection of serum BAFF level by enzyme-linked immunosorbent assay (ELISA). ${ }^{(20)}$

- Detection of serum APRIL level by ELISA. ${ }^{(22)}$ 


\section{Renal biopsy}

For the patients with Lupus Nephritis, All biopsies will be classified according to the modified WHO classification. ${ }^{(23)}$

Results of renal biopsies according to the modified World Health Organization Classification. ${ }^{(23)}$

\begin{tabular}{ll}
\hline Class & n \\
\hline I. Normal glomeruli & Nil \\
A. Nil by all techniques & \\
B. Normal by light microscopy but deposits seen by electron or immunofluorescence & \\
microscopy & 16 \\
II. Pure mesangial alterations (mesangiopathy) & 11 \\
A. Mesangial widening and mild hypercellularity (+) & 05 \\
B. Moderate hypercellulatiry (++) & \\
III. Focal segmental glomerulonephritis & 06 \\
A. Active necrotizing lesions & 05 \\
B. Active and sclerosing lesions & 01 \\
C. Sclerosing lesions & Nil \\
IV. Diffuse glomerulonephritis & 49 \\
A. Without segmental lesions & Nil \\
B. With active necrotizing lesions & 38 \\
C. With active and sclerosing lesions & 11 \\
D. With sclerosing lesions & Nil \\
V. Diffuse membranous glomerulonephritis & 07 \\
A. Pure membranous glomerulonephritis & Nil \\
B. Associated with lesions of category II (A or B) & 07 \\
VI. Advanced sclerosing glomerulonephritis & Nil \\
\hline
\end{tabular}

\section{Statistical analysis of the data}

Data were fed to the computer and analyzed using IBM SPSS software package version 20.0. Comparison between different groups regarding categorical variables was tested using Chi-square test. Normally quantitative data was compared using student t-test, or $\mathrm{F}$ test (ANOVA), abnormally distributed data was compared using Mann Whitney test or Kruskal Wallis test, Correlations between two quantitative variables were assessed using Pearson or Spearman coefficient according to test of normality. Significance of the obtained results was judged at the 0.05 level.

\section{RESULTS}

\section{Demographic data}

Table (1) shows demographic data of the studied groups, it demonstrated that:

Age ranged between 11-18, 11-18 and 12-17 years with the mean of $15.1 \square 2.66,16.1 \square 3.20$ and
15.47 $\square 2.94$ for group I, II and III respectively, there were no statistical significant differences between the three studied groups regarding age. $(\mathrm{P}=0.365)$

Sex: this study include 3 (15.0\%), 4 (20.0\%) and 5 (25.0\%) males and $18(85.0 \%), 16(80.0 \%)$ and 15 (75.0\%) females for group I, II and III respectively, there were no statistical significant differences between the three studied groups regarding sex. $(\mathrm{P}=0.621)$

Disease duration ranged between 3.0-20.0 and 4.0-24.0 months with the mean of $15.42 \square 4.25$, $16.01 \square 5.08$ months for group I and II respectively, there were no statistical significant differences between the two patients groups regarding disease duration. $(\mathrm{P}=0.407)$ 
Table (1): Demographic data of the studied groups

\begin{tabular}{|c|c|c|c|c|}
\hline & $\begin{array}{l}\text { Group I } \\
\text { "SLE patients with lupus } \\
\text { nephritis"“n=20" }\end{array}$ & $\begin{array}{l}\text { Group II } \\
\text { "SLE patients without } \\
\text { lupus nephritis" "n=20" }\end{array}$ & $\begin{array}{l}\text { Group III "control" } \\
\text { "n=20" }\end{array}$ & $\mathbf{p}$ \\
\hline $\begin{array}{l}\text { Age } \\
\text { Range } \\
\text { Mean } \pm \text { S.D. }\end{array}$ & $\begin{array}{l}11-18 \\
15.1 \pm 2.66 \\
\end{array}$ & $\begin{array}{l}11-18 \\
16.1 \pm 3.20\end{array}$ & $\begin{array}{l}12-17 \\
15.47 \pm 2.94\end{array}$ & 0.365 \\
\hline $\begin{array}{l}\text { Sex } \\
\text { Male } \\
\text { Female } \\
\end{array}$ & $\begin{array}{l}3(15.0 \%) \\
18(85.0 \%)\end{array}$ & $\begin{array}{l}4(20.0 \%) \\
16(80.0 \%)\end{array}$ & $\begin{array}{l}5(25.0 \%) \\
15(75.0 \%)\end{array}$ & 0.621 \\
\hline $\begin{array}{l}\text { Disease duration (months) } \\
\text { Range } \\
\text { Mean } \pm \text { S.D. }\end{array}$ & $\begin{array}{l}3.0-20.0 \\
15.42 \pm 4.25\end{array}$ & $\begin{array}{l}4.0-24.0 \\
16.01 \pm 5.08\end{array}$ & $\begin{array}{ll}- \\
- \\
- \\
\end{array}$ & 0.407 \\
\hline
\end{tabular}

\section{Clinical data}

Table (2) shows clinical data of the two studied patients group, it illustrated that,

Regarding mucocutaneous manifestations, group Ihas higher values than group II regarding photosensitivity $(60.0 \%$ and $60.0 \%)$, alopecia (30.0 and $15 \%)$ and vascular lesions $(25.0 \%$ and $15.0 \%)$ respectively. While, group Ilhas higher values than group I regarding oral ulceration $(25.0 \%, 10.0 \%)$ respectively.

Regarding articular complaints, group Ihas higher values than group II regarding arthralgia $(80.0 \%$ and $40.0 \%$ ), arthritis $(60.0 \%$ and $25.0 \%)$ respectively, while, group Ilhas higher values than group I regarding myositis $(15.0 \%$ and $5.0 \%)$ respectively.

Regarding constitutional manifestation, group Ihas higher values than group II regarding fatigue, loss of weight $(55.0 \%$ and $35.0 \%)$, while group II has higher values than group I regarding fever (25.0 and $20.0 \%$ ) respectively.
Regarding haematological, group Ihas higher values than group II regarding anemia (80.0\% and 70.0), leucopenia (30.0\% and 25.0) and thrombocytopenia (45.0\% and $25.0 \%)$ respectively.

Group Ilhas higher values than group I regarding ocular retinal changes (5.0\% and $0.0 \%)$ respectively. Group I has higher values than group II regarding hypertension $(25.0 \%$ and $0.0 \%$ ) respectively.

Regarding pulmonary manifestations, group Ihas higher values than group II regarding pleural effusion (15.0 and 10.0\%), respectively.

Regarding renal manifestations, nephritic syndrome and renal failure were found in group I only $(95.0 \%$ and $5.0 \%$ )

Regarding neuropsychiatric manifestations, seizure was found in $5.0 \%$ of group I only, while group I hashigher values than group II regarding headache (60.0\% and $15.0 \%$ ) respectively, group II has higher values than group I regarding depression $(30.0 \%$ and $5.0 \%$ ) respectively.

Table (2): Clinical data of the two studied patients group

\begin{tabular}{|l|l|l|l|l|}
\hline \multirow{2}{*}{} & \multicolumn{2}{|l|}{$\begin{array}{l}\text { Group I } \\
\text { "SLE patients with lupus } \\
\text { nephritis" “n=20" }\end{array}$} & $\begin{array}{l}\text { Group II } \\
\text { "SLE patients without lupus nephritis" } \\
\text { "n=20" }\end{array}$ \\
\cline { 2 - 5 } & No. & $\%$ & No. & $\%$ \\
\hline Mucocutaneous & & & & \\
\hline Oral ulceration & 2 & 10.0 & 5 & 25.0 \\
\hline Photosensitivity & 13 & 65.0 & 12 & 60.0 \\
\hline Alopecia & 6 & 30.0 & 3 & 15 \\
\hline Discoid rash & 0 & 0.0 & 0 & 0.0 \\
\hline Livedo-reticularis & 0 & 0.0 & 0 & 0.0 \\
\hline Vascular lesions & 5 & 25.0 & 3 & 15.0 \\
\hline Articular complaints & & & & \\
\hline Myositis & 1 & 5.0 & 3 & 15.0 \\
\hline Arthralgia & 16 & 80.0 & 8 & 40.0 \\
\hline
\end{tabular}




\begin{tabular}{|l|l|l|l|l|}
\hline Arthritis & 12 & 60.0 & 5 & 25.0 \\
\hline Avascular necrosis of hip & 0 & 0.0 & 1 & 5.0 \\
\hline Constitutional manifestation & & & & \\
\hline Fever & 4 & 20.0 & 5 & 25.0 \\
\hline Fatigue, loss of weight & 611 & 55.0 & 7 & 35.0 \\
\hline Haematological & & & & \\
\hline Anemia & 16 & 80.0 & 14 & 70.0 \\
\hline Leucopenia & 6 & 30.0 & 5 & 25.0 \\
\hline Thrombocytopenia & 9 & 45.0 & 5 & 25.0 \\
\hline Ocular retinal changes & 0 & 0.0 & 1 & 5.0 \\
\hline Hypertension & 5 & 25.0 & 0 & 0.0 \\
\hline Cardiac & & & & \\
\hline Precardial effusion & 2 & 10.0 & 3 & 15.0 \\
\hline Pulmonary & & & & \\
\hline Pleural effusion & 3 & 15.0 & 2 & 10.0 \\
\hline Pulmonary Embolism & 0 & 0.0 & 0 & 0.0 \\
\hline Renal & & & & \\
\hline Nephritic syndrome & 19 & 95.0 & 0 & 0.0 \\
\hline Renal failure & 1 & 5.0 & 0 & 0.0 \\
\hline Neuroyschiatric & & & & \\
\hline Seizure & 1 & 5.0 & 0 & 0.0 \\
\hline CVS & 0 & 0.0 & 0 & 0.0 \\
\hline Transvers myelitis & 0 & 0.0 & 0 & 0.0 \\
\hline Depression & 1 & 5.0 & 6 & 30.0 \\
\hline Headache & 12 & 60.0 & 3 & 15.0 \\
\hline
\end{tabular}

\section{Laboratory investigations}

Table (3) shows comparison between laboratory investigations in the two patients groups, it illustrated that,

\section{Haemoglobin concentration ( $\mathrm{g} / \mathrm{dl}$ )}

Haemoglobin concentration ranged between 8.0011.27 and 8.32-11.38 with the mean of $9.85 \square 1.86$ and $10.25 \square 1.68$ for group I and II respectively with no statistical significant differences $(\mathrm{P}=0.108)$

\section{RBCs count $\left(x 10^{3}\right.$ cell $\left./ \mathrm{mm}^{3}\right)$}

RBCs count ranged from 4.00-5.7 and 4.03-5.42 with the mean of $4.52 \square 0.58$ and $4.89 \square 0.33$ for group I and II respectively with no statistical significant differences $(\mathrm{P}=0.318)$.

\section{WBCs count $\left(x 10^{3}\right.$ cell/ $\left./ \mathrm{mm}^{3}\right)$}

WBCs count ranged from 2.11-7.1 and 2.78-8.77 with the mean of $4.52 \square 1.72$ and 5.01 $\square 2.17$ for group I and II respectively with no statistical significant differences $(\mathrm{P}=0.281)$.

\section{Platelet count $\left(x 10^{3} \mathrm{cell} / \mathrm{mm}^{3}\right)$}

Platelet count ranged from 32.23-325.0 and 46.00330.00 with the mean of $260.0 \square 82.71$ and $336.1 \square 89.6$ for group I and II respectively with no statistical significant differences $(\mathrm{P}=0.128)$

\section{$\operatorname{ALT}(\boldsymbol{U} / \mathrm{L})$}

ALT ranged from 11.2-45.0 and 14.03-37.0 for group I and II respectively with no statistical significant differences between the two studied groups $(\mathrm{P}=0.285)$.

\section{$\operatorname{AST}(\mathrm{U} / L)$}

AST ranged from 25.0-43.6 and 21.0-38.0 with the mean of $34.11 \square 9.75$ and $29.87 \square 8.25$ for group I and II respectively with no statistical significant differences between the two studied groups $(\mathrm{P}=0.451)$.

\section{$\operatorname{ESR}(\mathbf{m m})$}

ESR ranged from 30-100 and 25-95 with the mean of $68.0 \square 30.1$ and $65.1 \square 26.7$ for group I and II respectively with no statistical significant differences between the two studied groups $(\mathrm{P}=0.425)$. 


\section{$\operatorname{CRP}(m g / d l)$}

Positive CRP was found in $4(20.0 \%)$ and 1 (5.0\%), while negative CRP were found in 16 $(80.0 \%)$ and 19 (95.0\%) patients for group I and II respectively, with no statistical significant differences. $(\mathrm{P}=0.198)$

\section{Serum cholesterol (mg/dl)}

Serum cholesterol ranged between 70-110 and 68.9-161.0 with the mean of $95.3 \square 17.7$ and
105.1 $\square 18.2$ for group I and II respectively with no statistical significant differences $(\mathrm{P}=0.412)$.

Serum triglycerides ( $\mathrm{mg} / \mathrm{dl})$

Serum triglycerides ranged from 38-134 and 40116 with the mean of $88.6 \square 26.1$ and $84.5 \square 22.1$ for group I and II respectively with no statistical significant differences $(\mathrm{P}=0.611)$.

Table (3): Comparison between laboratory investigations in the two patients groups

\begin{tabular}{|c|c|c|c|}
\hline $\begin{array}{l}\text { Laboratory } \\
\text { investigations }\end{array}$ & $\begin{array}{l}\text { Group I } \\
\text { "SLE patients with lupus } \\
\text { nephritis" } \\
\text { "n=20" }\end{array}$ & $\begin{array}{l}\text { Group II } \\
\text { "SLE patients without lupus } \\
\text { nephritis" } \\
\text { "n=20" }\end{array}$ & $\mathbf{P}$ \\
\hline $\begin{array}{l}\text { HB }(\mathbf{g} / \mathbf{d l}) \\
\text { Range } \\
\text { Mean } \pm \text { S.D. }\end{array}$ & $\begin{array}{l}8.00-11.27 \\
9.85 \pm 1.86\end{array}$ & $\begin{array}{l}8.32-11.38 \\
10.25 \pm 1.68\end{array}$ & 0.108 \\
\hline $\begin{array}{l}\text { RBCs count }\left(\mathbf{x 1 0}^{3} \text { cell } / \mathbf{m m}^{3}\right) \\
\text { Range } \\
\text { Mean } \pm \text { S.D. }\end{array}$ & $\begin{array}{l}4.0-5.7 \\
4.52 \pm 0.58\end{array}$ & $\begin{array}{l}4.03-5.42 \\
4.89 \pm 0.33\end{array}$ & 0.318 \\
\hline $\begin{array}{l}\text { WBCs count }\left(\mathbf{x 1 0}^{3} \text { cell } / \mathbf{m m}^{3}\right) \\
\text { Range } \\
\text { Mean } \pm \text { S.D. }\end{array}$ & $\begin{array}{l}2.11-7.1 \\
4.52 \pm 1.72\end{array}$ & $\begin{array}{l}2.78-8.77 \\
5.01 \pm 2.17\end{array}$ & 0.281 \\
\hline $\begin{array}{l}\text { Platelet count }\left(\mathrm{x10}^{3} \text { cell } / \mathrm{mm}^{3}\right) \\
\text { Range } \\
\text { Mean } \pm \text { S.D. }\end{array}$ & $\begin{array}{l}32.23-325.0 \\
260.0 \pm 82.71\end{array}$ & $\begin{array}{l}46.00-330.00 \\
336.1 \pm 89.6\end{array}$ & 0.128 \\
\hline $\begin{array}{l}\text { ALT(U/L) } \\
\text { Range } \\
\text { Mean } \pm \text { S.D. }\end{array}$ & $\begin{array}{l}11.2-45.0 \\
27.13 \pm 8.63\end{array}$ & $\begin{array}{l}14.03-37.0 \\
25.61 \pm 5.17\end{array}$ & 0.285 \\
\hline $\begin{array}{l}\text { AST (U/L) } \\
\text { Range } \\
\text { Mean } \pm \text { S.D. }\end{array}$ & $\begin{array}{l}25.0-43.6 \\
34.11 \pm 9.75\end{array}$ & $\begin{array}{l}21.0-38.0 \\
29.87 \pm 8.25\end{array}$ & 0.451 \\
\hline $\begin{array}{l}\text { ESR }(\mathbf{m m}) \\
\text { Range } \\
\text { Mean } \square \text { S.D. }\end{array}$ & $\begin{array}{l}30-100 \\
68.0 \square 30.1\end{array}$ & $\begin{array}{l}25-95 \\
65.1 \square 26.7\end{array}$ & 0.425 \\
\hline $\begin{array}{l}\text { CRP }(\mathbf{m g} / \mathbf{d l}) \\
\text { Negative } \\
\text { Positive }\end{array}$ & $\begin{array}{l}16(80 \%) \\
4(20 \%)\end{array}$ & $\begin{array}{l}19(95.0 \%) \\
1(5.0 \%)\end{array}$ & 0.198 \\
\hline $\begin{array}{l}\text { Serum cholesterol }(\mathbf{m g} / \mathbf{d l}) \\
\text { Range } \\
\text { Mean } \square \text { S.D. }\end{array}$ & $\begin{array}{l}70-110 \\
95.3 \pm 17.7\end{array}$ & $\begin{array}{l}68.9 \pm 161.0 \\
105.1 \pm 18.2\end{array}$ & 0.412 \\
\hline $\begin{array}{l}\text { Serum triglycerides }(\mathbf{m g} / \mathbf{d l}) \\
\text { Range } \\
\text { Mean } \square \text { S.D. }\end{array}$ & $\begin{array}{l}38-134 \\
88.6 \pm 26.1\end{array}$ & $\begin{array}{l}40-116 \\
84.5 \pm 22.1\end{array}$ & 0.611 \\
\hline
\end{tabular}

\section{Kidney function}

Table (4) shows comparison between the two patients groups regarding kidney function, it demonstrated that,

\section{Blood urea $(\mathrm{mg} / \mathrm{dl})$}

Blood urea ranged from 50-130 and 10-41 with the mean of $105.6 \pm 26.5$ and $22.5 \pm 9.5$ for group I and II respectively with statistical significant differences between the two studied groups, group I (SLE patients with lupus nephritis) has statistically higher values than group II (SLE patients without lupus nephritis) $(\mathrm{P}=0.001)$. 


\section{Serum creatinine (mg/dl)}

Serum creatinine ranged from 1.4-6.0 and 0.31.01 with the mean of $3.65 \pm 1.22$ and $0.81 \pm 0.26$ for group I and II respectively with statistical significant differences between the two studied groups, group I has statistically higher values than group II $(\mathrm{P}=0.001)$.

\section{Urinary Alb/creatinine ratio}

It ranged from 28-227 and 15-27 with the mean of $115.6 \pm 69.8$ and $19.8 \pm 5.69$ for group I and II respectively with statistical significant differences between the two studied groups, group I has statistically higher values than group II $(\mathrm{P}=0.001)$.

\section{Proteinurea}

It ranged from640-6308 and 34-120 with the mean of $2520.6 \pm 780.77$ and $85.9 \pm 12.69$ for group I and II respectively with statistical significant differences between the two studied groups, group I has statistically higher values than group II $(\mathrm{P}=0.0001)$.

Table (4): Comparison between kidney function in the two patients groups.

\begin{tabular}{|c|c|c|c|}
\hline & $\begin{array}{l}\text { Group I } \\
\text { "SLE patients with } \\
\text { lupus nephritis" } \\
\text { "n=20" }\end{array}$ & $\begin{array}{l}\text { Group II } \\
\text { "SLE patients without } \\
\text { lupus nephritis" } \\
\text { "n=20" }\end{array}$ & $\mathbf{P}$ \\
\hline $\begin{array}{l}\text { Blood urea } \\
\text { Range } \\
\text { Mean } \pm \text { S.D. }\end{array}$ & $\begin{array}{l}50-130 \\
105.6 \pm 26.5\end{array}$ & $\begin{array}{l}10-41 \\
22.5 \pm 9.5\end{array}$ & $0.001 *$ \\
\hline $\begin{array}{l}\text { Serum creatinine } \\
\text { Range } \\
\text { Mean } \pm \text { S.D. }\end{array}$ & $\begin{array}{l}1.4-6.0 \\
3.65 \pm 1.22\end{array}$ & $\begin{array}{l}0.3-1.01 \\
0.81 \pm 0.26\end{array}$ & $0.001 *$ \\
\hline $\begin{array}{l}\text { GFR } \\
\text { Range } \\
\text { Mean } \pm \text { S.D. }\end{array}$ & $\begin{array}{l}25-62 \\
48.9 \pm 8.25\end{array}$ & $\begin{array}{l}75-92 \\
84.6 \pm 4.65\end{array}$ & $0.001 *$ \\
\hline $\begin{array}{ll}\text { Urinary } & \text { alb./creatinine } \\
\text { ratio } & \\
\text { Range } & \\
\text { Mean } \pm \text { S.D. } & \end{array}$ & $\begin{array}{l}28-227 \\
115.6 \pm 69.8\end{array}$ & $\begin{array}{l}15-27 \\
19.8 \pm 5.69\end{array}$ & $0.001 *$ \\
\hline $\begin{array}{l}\text { Proteinurea }(\mathbf{m g} / \mathbf{2 4 h}) \\
\text { Range } \\
\text { Mean } \pm \text { S.D. }\end{array}$ & $\begin{array}{c}640-6308 \\
2520.6 \pm 780.77\end{array}$ & $\begin{array}{l}34-120 \\
85.9 \pm 12.69\end{array}$ & $0.0001^{*}$ \\
\hline
\end{tabular}

\section{Immunological profile}

Immunological profile for the two studied patients groups were presented in Table (5), it showed that,

$A N A$

ANA ranged from 40-480 and 25-420 with the mean of $211.0 \pm 81.1$ and $196.1 \pm 58.6$ for group I and II respectively with no statistical significant differences between the two studied groups $(\mathrm{P}=0.214)$.

\section{Anti-DNA}

Anti-DNA ranged from30-275 and 30-285 with the mean of $125.6 \square 62.5$ and $132.6 \square 52.8$ for group I and II respectively with no statistical significant differences between the two studied groups $(\mathrm{P}=0.116)$.

\section{C3}

C3 ranged from 0.04-1.01 and 0.13-1.19 with the mean of $0.42 \pm 0.06$ and $0.68 \pm 0.075$ for group I and II respectively with statistical significant differences between the two studied groups, group II has statistically higher values than group I $(\mathrm{P}=0.041)$.

\section{C4}

C4 ranged from0.11-0.36 and 0.18-0.32 with the mean of $0.21 \square 0.06$ and $0.26 \square 0.045$ for group I and II respectively with no statistical significant differences between the two studied groups $(\mathrm{P}=0.621)$. 


\section{Renal activity index}

Renal activity index for group I (SLE patients with lupus nephritis) ranged between $0-8$ with the mean of $4.0 \pm 2.56$.

\section{Renal chronicity index}

Renal chronicity index for group I (SLE patients with lupus nephritis) ranged between 0-6 with the mean of $2.0 \pm 1.65$.

\section{WHO classification of lupus nephritis}

For group I, class II was found in $6(30.0 \%)$, class III was found in $9(45.0 \%)$ and class IV was found in $5(25.0 \%)$.

\section{Lupus activity index: (SLE DAI)}

Comparison between the two studied groups regarding the SLE DAI score was presented in table (6), it showed that, high activity score was found in $6(30.0 \%)$ and $4(20.0 \%)$, moderate activity score was found in $9(45.0 \%)$ and 9 (45.0\%), while low activity score was found in 5 $(25.0 \%)$ and $7(35.0 \%)$ for group I and II respectively, with no statistical significant differences. $(\mathrm{P}=0.123)$

Table (5): Immunological profile for the two studied patients group

\begin{tabular}{|l|l|l|l|}
\hline $\begin{array}{l}\text { Immunological } \\
\text { investigation }\end{array}$ & $\begin{array}{l}\text { Group I } \\
\text { "SLE patients with lupus } \\
\text { nephritis" } \\
\text { "n=20" }\end{array}$ & $\begin{array}{l}\text { Group II } \\
\text { "SLE patients without } \\
\text { lupus nephritis" } \\
\text { "n=20" }\end{array}$ & P \\
\hline $\begin{array}{l}\text { ANA } \\
\text { Range }\end{array}$ & $40-480$ & $25-420$ & \\
Mean \pm S.D. & $211.0 \pm 81.1$ & $196.1 \pm 58.6$ & 0.214 \\
\hline $\begin{array}{l}\text { Anti-DNA } \\
\text { Range }\end{array}$ Mean \pm S.D. & $30-275$ & $30-285$ & \\
\hline C3 & $125.6 \pm 62.5$ & $132.6 \pm 52.8$ & 0.116 \\
Range & $0.04-1.01$ & $0.13-1.19$ & \\
Mean \pm S.D. & $0.42 \pm 0.06$ & $0.68 \square 0.075$ & $0.041^{*}$ \\
\hline $\begin{array}{l}\text { C4 } \\
\text { Range }\end{array}$ & $0.11-0.36$ & $0.18-0.32$ & \\
Mean \pm S.D. & $0.21 \pm 0.06$ & $0.26 \pm 0.045$ & 0.621 \\
\hline Renal activity index & $0-8$ & - & \\
Range & $4.0 \pm 2.56$ & - & \\
Mean \pm S.D. & & - & \\
\hline Renal chronicity index & & - & \\
Range & $0-6$ & - & \\
Mean \pm S.D. & $2.0 \pm 1.65$ & - & \\
\hline WHO classification of & & - & \\
lupus nephritis & $6(30.0)$ & $9(45.0 \%)$ & \\
Class II & Class III \\
Class IV & $5(25.0 \%)$ & & \\
\hline
\end{tabular}

Table (6): Comparison between the two studied groups regarding the SLE DAI score

\begin{tabular}{|l|l|l|l|l|}
\hline & \multicolumn{2}{|l|}{$\begin{array}{l}\text { Group I } \\
\text { "SLE patients with lupus nephritis" } \\
\text { “n=20" }\end{array}$} & \multicolumn{2}{l|}{$\begin{array}{l}\text { Group II } \\
\text { "SLE patients without lupus nephritis" } \\
\text { "n=20" }\end{array}$} \\
\cline { 2 - 5 } & No & $\%$ & No. & $\%$ \\
\hline High & 6 & 30.0 & 4 & 20.0 \\
\hline Moderate & 9 & 45.0 & 9 & 45.0 \\
\hline Low & 5 & 25.0 & 7 & 35.0 \\
\hline p & 0.123 & \multicolumn{3}{l}{} \\
\hline
\end{tabular}




\section{BAFF and APRIL}

Table (7) shows BAFF and APRIL in the studied groups, it demonstrated that:

\section{BAFF}

BAFF ranged from 4.26-182., 3.25-166.0 and 2.130.0 with the mean of $88.6 \pm 42.6,69.2 \pm 27.6$ and $12.9 \pm 3.25$ for group I, II and III respectively, there were statistical significant differences between the three studied groups regarding BAFF, group I has statistically higher values than group
II and III, also group II has statistically higher values than group III. $(\mathrm{P}=0.001)$

\section{APRIL}

APRIL ranged from3.0-40.0, 2.0-42.5 and 7.045.0 with the mean of $7.98 \pm 8.25,9.12 \pm 7.88$ and $14.89 \pm 7.98$ for group I, II and III respectively, there were statistical significant differences between the three studied groups regarding APRIL, group IIIhas statistically higher values than group I and II, also group II has statistically higher values than group I. $(\mathrm{P}=0.0025)$

Table (7): BAFF and APRIL in different studied groups

\begin{tabular}{|c|c|c|c|c|}
\hline & $\begin{array}{l}\text { Group I } \\
\text { "SLE patients with } \\
\text { lupus nephritis" } \\
\text { "n=20" }\end{array}$ & $\begin{array}{l}\text { Group II } \\
\text { "SLE patients without } \\
\text { lupus nephritis" } \\
\text { "n=20" }\end{array}$ & $\begin{array}{l}\text { Group III "control" } \\
\text { "n=20" }\end{array}$ & p \\
\hline $\begin{array}{l}\text { BAFF } \\
\text { Range } \\
\text { Mean } \pm \text { S.D. }\end{array}$ & $\begin{array}{l}4.26-182.0 \\
88.6 \pm 42.6\end{array}$ & $\begin{array}{l}3.25-166.0 \\
69.2 \pm 27.6\end{array}$ & $\begin{array}{l}2.1-30.0 \\
12.9 \pm 3.25\end{array}$ & $0.001^{*}$ \\
\hline $\begin{array}{l}\text { APRIL } \\
\text { Range } \\
\text { Mean } \pm \text { S.D. }\end{array}$ & $\begin{array}{l}3.0-40.0 \\
7.98 \pm 8.25\end{array}$ & $\begin{array}{l}2.0-42.5 \\
9.12 \pm 7.88\end{array}$ & $\begin{array}{l}7.0-45.0 \\
14.89 \pm 7.98\end{array}$ & $0.0025^{*}$ \\
\hline
\end{tabular}

\section{Correlations}

Table (8) shows correlations between serum BAFF and APRIL with immunological profile, disease duration and activity of disease in the two patients groups, it illustrated that,

Regarding group I, there was positive significant correlation between ANA, activity index and chronicity index with BAFF, there was negative significant correlation between ANA, activity index, and chronicity index with APRIL.

Regarding group II, there waspositive significant correlation between ANA and Anti-DNA with BAFF, while there was negative significant correlation between ANA with APRIL.
Table (9) shows relation between disease activity and BAFF, APRIL levels, it demonstrated that, the mean of BAFF values was $98.8 \pm 38.6$, $80.2 \pm 35.9$ and $71.6 \pm 39.5$ for high, moderate and low in group I, while in group II the mean of BAFF values was $82.6 \pm 21.3,74.2 \pm 26.5$ and $60.2 \pm 31.2$ for high, moderate and low disease activity, with statistical significant differences

The mean of APRIL value was16.25 \pm 3.01 , $10.12 \pm 2.78,8.23 \pm 3.95$ for high, moderate and low in group I, while in group II the mean of APRIL valuewas $11.6 \pm 3.41,9.58 \pm 3.21$ and $7.98 \pm 2.85$ for high, moderate and low disease activity, with statistical significant differences

Table (8): Correlation between BAFF and APRIL and immunological profile and disease duration and activity of disease in the two patients group

\begin{tabular}{|l|l|l|l|l|}
\hline & $\begin{array}{l}\text { Group I } \\
\text { "SLE patients with lupus nephritis" } \\
\text { “n=20" }\end{array}$ & $\begin{array}{l}\text { Group II } \\
\text { "SLE patients without lupus nephritis" } \\
\text { "n=20" }\end{array}$ \\
\hline BAFF \# & $\mathbf{r}$ & $\mathbf{p}$ & $\mathbf{r}$ & $\mathbf{p}$ \\
\hline ANA & 0.411 & $0.01 *$ & 0.511 & $0.003 *$ \\
\hline Anti-DNA & 0.125 & 0.236 & 0.258 & $0.046^{*}$ \\
\hline C3 & 0.098 & 0.456 & 0.107 & 0.365 \\
\hline C4 & 0.11 & 0.277 & 0.206 & 0.211 \\
\hline
\end{tabular}




\begin{tabular}{|l|l|l|l|l|}
\hline Activity index & 0.369 & $0.013^{*}$ & & \\
\hline Chronicity index & 0.468 & $0.002^{*}$ & & \\
\hline APRIL\# & & & & \\
\hline ANA & 0.398 & $0.021^{*}$ & 0.426 & $0.015^{*}$ \\
\hline Anti-DNA & 0.223 & 0.107 & 0.109 & 0.365 \\
\hline C3 & 0.17 & 0.269 & 0.11 & 0.411 \\
\hline C4 & 0.221 & 0.11 & 0.207 & 0.288 \\
\hline Activity index & 0.39 & $0.019^{*}$ & & \\
\hline Chronicity index & 0.44 & $0.002^{*}$ & & \\
\hline
\end{tabular}

Table (9): Relation between disease activity and BAFF, APRIL level

\begin{tabular}{|l|l|l|}
\hline & $\begin{array}{l}\text { Group I } \\
\text { "SLE patients with lupus nephritis" } \\
\text { “n=20" }\end{array}$ & $\begin{array}{l}\text { Group II } \\
\text { "SLE patients without lupus nephritis" } \\
\text { “n=20" }\end{array}$ \\
\hline BAFF & & \\
\hline High & $98.8 \pm 38.6$ & $82.6 \pm 21.3$ \\
\hline Moderate & $80.2 \pm 35.9$ & $74.2 \pm 26.5$ \\
\hline Low & $71.6 \pm 39.5$ & $60.2 \pm 31.2$ \\
\hline $\mathbf{p}$ & $0.012^{*}$ & $0.003^{*}$ \\
\hline APRIL & & \\
\hline High & $16.25 \pm 3.01$ & $11.6 \pm 3.41$ \\
\hline Moderate & $10.12 \pm 2.78$ & $9.58 \pm 3.21$ \\
\hline Low & $8.23 \pm 3.95$ & $7.98 \pm 2.85$ \\
\hline p & $0.012^{*}$ & $0.014^{*}$ \\
\hline
\end{tabular}

\section{DISCUSSION}

Lupus nephritis is one of the most frequent and serious complications for patients with SLE and has a profound effect on both morbidity and mortality. Dysfunction of the B cells, an important component of adaptive immunity, is thought to be important in the pathogenesis of SLE/LN. The production of pathogenic antibody has been traditionally viewed as the principle contribution of $\mathrm{B}$ cells to the pathogenesis of immunemediated glomerulonephritis ${ }^{(24)}$.

B-cell activating factor (BAFF, also known as Blymphocyte stimulator, BLyS) belongs to the tumor necrosis factor (TNF) superfamily and can be produced by myeloid cells such as monocytes, macrophages, dendritic cells, and neutrophils. BAFF contributes to B-cell proliferation and differentiation, and it is important in immunoglobulin class switching ${ }^{(25)}$. Many researchers have demonstrated that high levels of BAFF may relax B-cell selection and contribute to autoantibody production, exacerbating proteinuria and renal inflammation in SLE ${ }^{(26)}$. Like BLyS, APRIL is a member of the TNF family, and is thought to have a regulatory role in B cell proliferation.

The aim of this study was to investigate the serum level of BAFF, APRIL in Egyptian adolescent lupus nephritis patients and correlate their level with grade and chronicity index of $\mathrm{LN}$ and compare their result with their counterparts of adolescent lupus patients without lupus nephritis. This study included 60 adolescent patients: Group 1: 20 adolescent SLE patients with lupus nephritis. Group 2: 20 adolescent SLE patients without lupus nephritis. Group 3: 20 age and sex matched healthy subjects served as control group. In this study, serum BLyS levels was statistically higher in group I (SLE with nephritis) than group II (SLE without nephritis) and the least was in the control group.

In agreement with our study, numerous studies have shown that serum BLyS levels are elevated in patients with SLE compared with controls,. ${ }^{(27)}$

Our study showed that, serum APRIL level ingroup III has statistically higher values than group I and II, also group II has statistically higher values than group I. 
In disagreement with our study, APRIL levels have been shown to be elevated in patients with lupus compared with healthy controls, although one study has found that levels may be lower in patients with lupus nephritis compared with patients who have lupus without kidney involvement. ${ }^{(28,29)}$

Vincent, et al., (2013) demonstrated that, there was a trend toward a higher BAFF/APRIL ratio amongst SLE patients with renal disease. These data indicated that among patients with renal involvement, serum concentrations of BAFF and APRIL were significantly different to those without these manifestations. ${ }^{(29)}$

In agreement with our study, Vincent, et al., (2013) determine whether serum concentrations of $\mathrm{B}$ cell activating factor from the tumour necrosis factor family (BAFF) and/or a proliferationinducing ligand (APRIL) are associated with clinical manifestations of systemic lupus erythematosus (SLE). They found that, serum BAFF was significantly increased, and APRIL decreased, in patients with renal lupus. In contrast, in cross-sectional analysis, there was no correlation between disease activity (SLEDAI-2k) and serum BAFF or APRIL, while the only disagreement with our study, was the positive significant correlation of serum BAFF with SLE activity index. ${ }^{(29)}$

Petri, et al., (2008) ${ }^{(30)}$ and Hegazy et al., (2010) ${ }^{(31)}$ illustrated that, disease activity levels have been correlated with serum BAFF and APRIL, but this association was not observed in other studies. ${ }^{(32,33)}$ The lack of correlation of serum BAFF and APRIL concentrations with disease activity in cross-sectional analysis does not preclude the possibility that measurement of these cytokines could be associated with disease activity in individual patients over time, for example because of differences between subjects' baseline concentrations. ${ }^{(29)}$

Many studies of potential biomarkers have failed to yield evidence of useful correlations with composite measures of disease activity. ${ }^{(34)}$ It has recently been suggested that the investigation of phenotypic subsets based on clinical manifestations, in addition to analysis of overall disease activity, may have merit. ${ }^{(35)}$ Several lines of evidence support this approach. Murine studies suggest that different manifestations of SLE may be determined by different immunological mechanisms. ${ }^{(36),}$ Moreover, studies in human SLE of the IFN $\alpha$ pathway suggest that the expression of IFN-induced genes associates with clinical subgroups, such as patients with renal disease, despite not varying with overall disease activity. ${ }^{(37)}$ Of note, the actions of IFN $\alpha$ include upregulation of BAFF expression. ${ }^{(38)}$

In agreement with our study, Petri, et al., $(2008)^{(30)}$ and Hegazy et al., (2010) ${ }^{(31)}$ showed that, anti-dsDNA antibodies levels have been correlated with serum BAFF and APRIL, but this association was not observed in other studies ${ }^{(39,40)}$, our study showed no significant correlation between serum APRIL and anti-DNA levels, while it showed a positive significant correlation with ANA levels

\section{CONCLUSIONS}

From our study, we concluded that, serum BAFF and APRIL concentrations could be used as new noninvasive biomarkers that could

distinguish a clinical subset of SLE patients, in this case those with renal SLE and the use of Anti BAFF (belimumab) as a new hope for treatment of patients with lupus nephritis.

\section{REFERENCES}

1. Mok CC, Tang SS, To CH, et al. Incidence and risk factors of thromboembolism in systemic lupus erythematosus: a comparison of three ethnic groups. Arthritis Rheum. 2005;52:2774-82.

2. Bastian HM,Roseman JM, McGwin G Jr., et al .; LUMINA Study Group. LUpus in MInority populations: NAturevs nurture. Systemic lupus erythematosus in three ethnic groups. XII. Risk factors for lupus nephritis after diagnosis. Lupus. 2002; 11:152-60. 
3. Mok CC,Tang SS. Incidence and predictors of renal disease in Chinese patients with systemic lupus erythematosus. Am J Med 2004;117:7915.

4. Appenzeller S, Clarke AE, Panopalis P, et al. The relationship between renal activity and quality of life in systemic lupus erythematosus. J Rheumatol 2009;36:94752.

5. Mok CC, Kwok RC, Yip PS. Effect of renal disease on the standardized mortality ratio and life expectancy of patients with systemic lupus erythematosus. Arthritis Rheum 2013;65:2154-60.

6. Ramanujam M, Bethunaickan R, Huang W et al. Selective blockade of BAFF for the prevention and treatment of systemic lupus erythematosus nephritis in NZM2410 mice. Arthritis Rheum 2010; 62:1457-68.

7. 7. Mackay F, Woodcock SA, Lawton $P$ et al. Mice transgenic for BAFF develop lymphocytic disorders along with autoimmune manifestations. J Exp Med 1999;190:1697-710.

8. Cheema GS, Roschke V, Hilbert DM et al. Elevated serum B lymphocyte stimulator levels in patients with systemic immune-based rheumatic diseases. Arthritis Rheum 2001;44:1313-19.

9. Zhang J, Roschke V, Baker KP et al. Cutting edge: a role for B lymphocyte stimulator in systemic lupus erythematosus. J Immunol 2001;166:6-10.

10. Stohl W, Metyas S, Tan SM et al. B lymphocyte stimulator overexpression in patients with systemic lupus erythematosus: longitudinal observations. Arthritis Rheum 2003;48:3475-86.

11. Zhao LD, Li Y, Smith MF Jr et al. Expressions of BAFF/BAFF receptors and their correlation with disease activity in Chinese SLE patients. Lupus 2010;19:1534-49.
12. Vincent FB, Northcott $M$, Hoi A et al. Association of serum $B$ cell activating factor from the tumour necrosis factor family (BAFF) and a proliferationinducing ligand (APRIL) with central nervous system and renal disease in systemic lupus erythematosus. Lupus 2013; 22:873-84.

13. Neusser MA, Lindenmeyer MT, Edenhofer I et al. Intrarenal production of B-cell survival factors in human lupus nephritis. Mod Pathol 2011; 24:98-107.

14. Stein JV, Lopez-Fraga M, Elustondo FA et al. APRIL modulates $\mathrm{B}$ and $\mathrm{T}$ cell immunity. J Clin Invest 2002;109:1587-98

15. Dillon SR, Gross JA, Ansell SM et al. An APRIL to remember: novel TNF ligands as therapeutic targets. Nat Rev Drug Discov 2006; 5:235-46

16. Hegazy M, Darwish H, Darweesh H et al. Raised serum level of APRIL in patients with systemic lupus erythematosus: correlations with disease activity indices. ClinImmunol 2010;135:118-24

17. Koyama T, Tsukamoto H, Miyagi Y et al. Raised serum APRIL levels in patients with systemic lupus erythematosus. Ann Rheum Dis 2005; 64:1065-7

18. Vallerskog T, Heimburger M, Gunnarsson I et al. Differential effects on BAFF and APRIL levels in rituximab-treated patients with systemic lupus erythematosus and rheumatoid arthritis. Arthritis Res Ther 2006; 8:R167

19. Michelle Petri, Ana-Maria Orbai, Graciela S. Alarcón, Caroline Gordon, Joan T. Merrill, Paul R. Fortin, et al. Derivation and Validation of Systemic Lupus International Collaborating Clinics Classification Criteria for Systemic Lupus Erythematosus. Arthritis Rheum. 2012; 64(8): 2677-2686.

20. Maneini G, Caronora AO, Herman JF. Immunochemical quantitation of antigen 
by single radial immunodiffusion. Immunochemistry 1965; 2:253-7.

21. Becker-Merok A, Nikolaisen C, Nossent HC. B-lymphocyte activating factor in systemic lupus erythematousus and rheumatoid arthritis in relation to autoantibody levels, disease measures and time. Lupus 2006; 15(9): 570-6.

22. Tan SM, Xu D, Roschke V, Perry JW, Arkfeld DG, Ehresmann GR, et al. local production of B lymphocyte stimulator protein and APRIL in arthritic joints of patients with inflammatory arthritis. Arth Rheum 2003; 48 (4): 982-92.

23. Zapitelli M, Duffy C, Bernard C, Succimarri R, Watanabe Duffy K, Kagan $\mathrm{R}$, et al. Clinicopathological study of the WHO classification in childhood lupus nephritis. PediatrNephrol. 2004; 19: 503510.

24. SalamaA. D. and C. D. Pusey, "Drug insight: Rituximab in renal disease and transplantation," Nature Clinical Practice Nephrology. 2006; 2: 221-230, 2006.

25. CancroM. P., D. P. D'Cruz, and M. A. Khamashta, "The role of B lymphocyte stimulator (BLyS) in systemic lupus erythematosus," Journal of Clinical Investigation.2009; 119: 1066-1073.

26. ChuV. T., P. Enghard, S. Schürer et al., "Systemic activation of the immune system induces aberrant BAFF and APRIL expression in B cells in patients with systemic lupus erythematosus," Arthritis and Rheumatism. 2009; 60: 2083-2093.

27. Stohl W, Hilbert DM The discovery and development of belimumab: the anti-Blyslupus connection. Nat Biotechnol. 2012;30:69-77.

28. Koyama T, Tsukamoto H, Miyani Y et al. Raised serum APRIL levels in patients with systemic lupus erythematosus. Ann Rheum Dis 2005;64:1065-7.

29. Vincent FB, Northcott M, Hoi A et al. Association of serum $\mathrm{B}$ cell activating factor from the tumour necrosis factor family (BAFF) and a proliferationinducing ligand (APRIL) with central nervous system and renal disease in systemic lupus erythematosus. Lupus 2013;22:873-84.

30. Petri M, Stohl W, Chatham W, et al. Association of plasma B lymphocyte stimulator levels and disease activity in systemic lupus erythematosus. Arthritis Rheum 2008; 58: 2453-2459.

31. Hegazy M, Darwish H, Darweesh H, ElShehaby A, Emad Y. Raised serum level of APRIL in patients with systemic lupus erythematosus: Correlations with disease activity indices. ClinImmunol 2010; 135: 118-124.

32. Morel J, Roubille C, Planelles L, et al. Serum levels of tumour necrosis factor family members a proliferation-inducing ligand (APRIL) and B lymphocyte stimulator (BLyS) are inversely correlated in systemic lupus erythematosus. Ann Rheum Dis 2009; 68: 997-1002.

33. Stohl W, Hiepe F, Latinis KM, et al .Belimumab reduces autoantibodies, normalizes low complement levels, and reduces select $\mathrm{B}$ cell populations in patients with systemic lupus erythematosus. Arthritis Rheum 2012; 64: 2328-2337.

34. Illei GG, Tackey E, Lapteva L, Lipsky PE. Biomarkers in systemic lupus erythematosus: II. Markers of disease activity. Arthritis Rheum 2004; 50: 2048 2065.

35. Bertsias GK, Salmon JE, Boumpas DT. Therapeutic opportunities in systemic lupus erythematosus: State of the art and prospects for the new decade. Ann Rheum Dis 2010; 69: 1603-1611.

36. Vuyyuru R, Mohan C, Manser T, Rahman ZS The lupus susceptibility locus Sle1 breaches peripheral B cell tolerance at the antibody-forming cell and germinal center 
checkpoints. J Immunol 2009; 183: 57165727.

37. Feng X, Wu H, Grossman JM, et al. Association of increased interferoninducible gene expression with disease activity and lupus nephritis in patients with systemic lupus erythematosus. Arthritis Rheum 2006; 54: 2951-2962.

38. Rönnblom L. Potential role of IFNalpha in adult lupus. Arthritis Res Ther 2010; 12(Suppl 1): S3-S3.

39. Morel J, Roubille C, Planelles L, et al. Serum levels of tumour necrosis factor family members a proliferation-inducing ligand (APRIL) and B lymphocyte stimulator (BLyS) are inversely correlated in systemic lupus erythematosus. Ann Rheum Dis 2009; 68: 997-1002.

40. Stohl W, Hiepe F, Latinis KM, et al. Belimumab reduces autoantibodies, normalizes low complement levels, and reduces select $\mathrm{B}$ cell populations in patients with systemic lupus erythematosus. Arthritis Rheum 2012; 64: 2328-2337. 